\begin{tabular}{|l|l|l|}
\hline \multicolumn{2}{|c|}{ PublisherInfo } \\
\hline \hline PublisherName & $:$ & BioMed Central \\
\hline \hline PublisherLocation & $:$ & London \\
\hline \hline PublisherImprintName & $:$ & BioMed Central \\
\hline \hline
\end{tabular}

\title{
Progostic LOH markers for breast cancer
}

\begin{tabular}{|l|l|l||}
\hline \multicolumn{2}{|c||}{ ArticleInfo } \\
\hline \hline ArticleID & $:$ & 3659 \\
\hline \hline ArticleDOI & $:$ & $10.1186 /$ bcr-1999-66637 \\
\hline \hline ArticleCitationID & $:$ & 66637 \\
\hline \hline ArticleSequenceNumber & $:$ & 25 \\
\hline \hline ArticleCategory & $:$ & Paper Report \\
\hline \hline ArticleFirstPage & $:$ & 1 \\
\hline \hline ArticleLastPage & $:$ & 4 \\
\hline \hline & & RegistrationDate : 1999-10-26 \\
ArticleHistory & $:$ & OnlineDate $1999-10-26$ \\
\hline \hline ArticleCopyright & $:$ & Current Science Ltd1999 \\
\hline \hline ArticleGrants & $:$ & \\
\hline \hline ArticleContext & $:$ & 1305822 \\
\hline \hline
\end{tabular}




\section{Keywords}

$\mathrm{LOH}$, postoperative prognosis

\section{Introduction}

Loss of heterozygosity (LOH) at a number of loci, many of which include tumour suppressor genes, has been implicated in breast cancer. The prognostic significance of several genetic alterations has previously been established, but does not currently influence treatment decisions. Having previously examined 150 loci on an average of 200 breast cancers, this study uses representative markers at 18 loci on breast cancers from 264 women. Correlations are made with postoperative prognosis after 5 year follow-up.

\section{Aims}

To identify which LOH markers, or groups of markers, are of significant prognostic value in breast cancer.

\section{Comments}

This is not the first study to identify prognostic relevance for LOH markers, but it does investigate a large number of implicated loci in a large cohort of patients (whereas most other studies are limited to specific loci in fewer patients). It is a shame that not all relevant survival data is available and that correlations between specific LOH markers and histopathological characteristics were not more fully explored. Nevertheless, the importance of further similar studies (and the collection of suitable material together with clinical data to allow such studies) is clearly demonstrated. Whether any genetic markers are adopted for clinical use is still open to debate.

\section{Methods}


264 patients who underwent surgery for breast cancer (between 1990 and 1992 at Cancer Institute Hospital, Tokyo) were followed clinically for 5 years or until death. All clinical and histopathological data was recorded. Postoperative survival data, but not disease-free survival or relapse was available. All tumour and non-cancerous samples were frozen and DNA extracted as detailed previously.LOH analysis was performed by PCR on 10ng of genomic DNA with ${ }^{32} \mathrm{P}$-labelled forward primers, Detection was by autoradiographic exposure and $\mathrm{LOH}$ scored when $>50 \%$ reduction in signal intensity was seen for either marker. A total of 18 markers covering 13 chromosomal arms were used.

\section{Results}

Clinical characteristics of the 264 tumours are listed including: median age $=52$; tumour stage $(158=\mathrm{t} 2)$; nodal status $(120=$ negative $)$; menopausal status $(132=$ pre $)$; ER status $(115=+)$; PR status $(159=+)$ and survival $(45=$ dead $)$.

$\mathrm{LOH}$ was detected to varying degrees:

$$
\begin{aligned}
& 1 \mathrm{p} 36(\mathrm{D} 1 \mathrm{~S} 612)=31 \% ; 1 \mathrm{p} 34(\mathrm{D} 1 \mathrm{~S} 552)=29 \% ; 1 \mathrm{p} 22(\mathrm{D} 1 \mathrm{~S} 551)=25 \% ; 3 \mathrm{p} 25.1 \\
& (\mathrm{D} 3 \mathrm{~S} 1286)=24 \% ; 3 \mathrm{p} 14.3(\mathrm{D} 3 \mathrm{~S} 1295)=44 \% ; 6 \mathrm{q} 26-27(\mathrm{D} 6 \mathrm{~S} 503)=41 \% ; 8 \mathrm{p} 22 \\
& (\mathrm{D} 8 \mathrm{~S} 136)=49 \% ; 9 \mathrm{p} 21-22(\mathrm{D} 9 \mathrm{~S} 157)=26 \% ; 11 \mathrm{p} 15(\mathrm{D} 11 \mathrm{~S} 922)=25 \% ; 11 \mathrm{q} 23-24 \\
& (\mathrm{D} 11 \mathrm{~S} 1998)=48 \% ; 13 q 12(\mathrm{D} 13 \mathrm{~S} 171)=36 \% ; 13 \mathrm{q} 14(\mathrm{D} 13 \mathrm{~S} 270)=34 \% ; 16 \mathrm{q} 24.3 \\
& (\mathrm{D} 16 \mathrm{~S} 413)=57 \% ; 17 \mathrm{p} 13.3(\mathrm{D} 17 \mathrm{~S} 849)=53 \% ; 17 \mathrm{p} 13.1(\mathrm{TP} 53)=54 \% ; 17 \mathrm{q} 21.1 \\
& (\mathrm{D} 17 \mathrm{~S} 934)=41 \% ; 18 q 21.1(\mathrm{D} 18 \mathrm{~S} 474)=30 \% ; 22 \mathrm{q} 13(\mathrm{D} 22 \mathrm{~S} 272)=33 \%
\end{aligned}
$$

Co-ordinate losses were identified in 1p34+13q12, 1p34+17p13.3, 1p34+17q21.1, 13q12+17p13.3 and $17 q 13.3+17 q 21.1$. Four markers and two pairs of markers were found to have significant prognostic value and carried significant relative risk of death $(R R)$ :

$1 \mathrm{p} 34-\mathrm{P}=0.0047, \mathrm{RR}=2.3 ; 13 \mathrm{q} 12-\mathrm{P}=0.0062, \mathrm{RR}=3.1 ; 17 \mathrm{p} 13.3-\mathrm{P}=0.0008, \mathrm{RR}=3.8 ;$ $17 \mathrm{q} 21.1-\mathrm{P}=0.0259, \mathrm{RR}=1.8 ; 1 \mathrm{p} 34$ and $17 \mathrm{p} 13.3-\mathrm{P}=0.0001, \mathrm{RR}=8.6 ; 13 \mathrm{q} 12$ and $17 \mathrm{p} 13.3-\mathrm{P}=$ $0.0064, \mathrm{RR}=9.6$.

Clinical parameters for informative patients at each of the four prognostic loci are given. $\mathrm{LOH}$ at $13 \mathrm{q} 12$ or $17 \mathrm{p} 13.3$ were found to be independent markers by multivariate analysis with hazard ratios of 3.1 and 2.7 respectively.New marker sets of three markers at each loci were shown to be $100 \%$ informative when combined.Due to wide treatment variation in this cohort, no attempt was made to correlate $\mathrm{LOH}$ with survival in individual treatment regimens. 


\section{Discussion}

Prognostic factors have become increasingly important in prediction of postoperative prognosis and treatment management. Those currently used mostly consist of conventional histopathological characteristics, although previous studies have assessed the suitability of genetic alterations. Here four loci have been implicated as having significant prognostic value.

Two of these loci (17p21.1 and 13q12) are the locations of the BRCA1 and BRCA2 genes. Whilst mutation in these genes is rare in sporadic cancer this study supports the previously postulated possibility that haploinsufficiency is involved in breast cancer predisposition and extends this to a role in aggressive clinical phenotype.

The prognostic loss at 17p13.3 implicates an unidentified tumour supressor gene distinct from TP53 in poor survival.

Application of these LOH markers, separately or in combination, may allow the selection of patients for intensive adjuvant therapy.

\section{References}

1. Emi M, Yoshimoto M, Sato T, Matsumoto S, Utada Y, Ito I, Minobe K, Iwase T, Katagiri T, Bando K, Akiyama F, Harada Y, Fukino K, Sakamoto G, Matsushima M, Iida A, Tada T, Saito H, Miki Y, Kasumi F, Nakamura Y: Allelic loss at 1p34, 13q12, 17p13.3, and 17q21.1 correlates with poor postoperative prognosis in breast cancer. Genes Chromosomes Cancer. 1999, 26: 134-141. 